\title{
Building a Golden Grove 'community': a study of suburban production processes in South Australia, 1970s-1980s
}

\author{
Caryl Bosman* \\ Urban Research Program, Griffith School of Environment, Griffith University,, Gold Coast campus, \\ Queensland 4222, Australia
}

\begin{abstract}
Ideals of community have been associated with the practice of planning for over a century. Proponents of the Golden Grove Development considered particular ideals of community to be fundamental to the financial and social success of the new suburban development. This paper will analyse the early planning processes that underpinned the production of community ideals and argue that these planning processes took place at the transition between welfarism and neo-liberalism. This study will offer provocative glimpses into late twentieth century suburban planning practices; practices that establish the Golden Grove Development as a model of late twentieth century suburban production processes.
\end{abstract}

Keywords:

\section{Introduction}

The Golden Grove Development is a recent (1985-2003) 'fully planned community' development situated on the fringes of Metropolitan Adelaide in the state of South Australia (see Figure 1). The area was earmarked for residential development in 1962 and studies and planning proposals for the site began in the early 1970s. These reports were commissioned, as a State/Federal Government project, by the South Australian State Government. By the time development of the new suburban area commenced (1985) the political climate had shifted and the project was no longer considered by the State Government as an initiative of the Government. Instead the State Government entered into a joint venture partnership, ratified by indenture, with the Delfin Property Group (now Delfin Lend Lease) for the development of a master planned community.

The developers (the State Government and Delfin) of the Golden Grove site considered ideals of community to be fundamental to the financial success of the project. As I have argued elsewhere, the planning techniques and practices that were ascribed to the manifestation of these ideals - and the development as a whole - were significant in establishing this suburban site as a late twentieth century model of suburban development. ${ }^{1}$ Stephen Hamnett and Alan Hutchings write that the 'Golden Grove [Development] provides an excellent example of the state of art in South Australian suburban development in the late 1980s and early 1990s'. ${ }^{2}$ It is important to acknowledge that while the suburban processes that produced the development were 'state of art' at the time, the final product - The Golden Grove Development - reflects processes and related outcomes that have serious social and environmental 


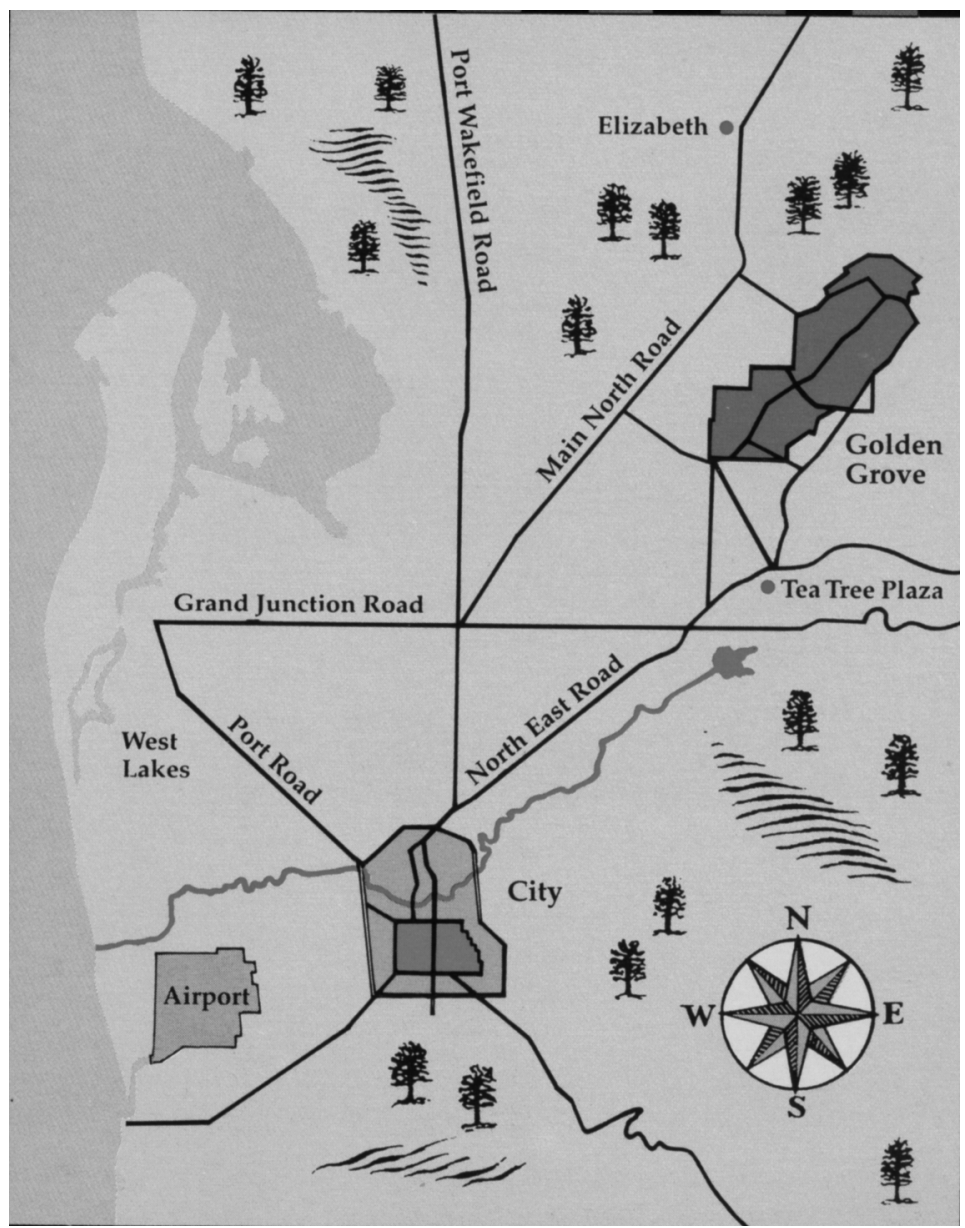

Figure 1. Location plan of the Golden Grove Development site. Source: Image courtesy of Delfin Lend Lease.

implications. The site covers approximately 1230 hectares, 980 of which are allocated for building, 190 hectares for natural reserves and 60 hectares for green space. ${ }^{3}$ The development comprises over 10,000 allotments, is home to approximately 30,000 residents and includes public and private schools, a recreation and arts centre, a shopping precinct and a number of recreation facilities.

The significance of the Golden Grove Development can be demonstrated by analysing the techniques and practices that informed the built landscape. That is, the importance of the Golden Grove Development is embedded in knowledges that depict how ideals of community were constituted in the late twentieth century. The development represents a period of change, a shift in modes of government, from welfarism to neo-liberalism. The histories analysed here do not constitute a definitive reading of welfarism and neo-liberalism. My aim is to place the 
early planning (1970s-80s) of the Golden Grove Development within the political context of the time and thereby reveal some of the techniques and practices through which and by which the development was invested with particular ideals of the 'good community'. These ideals per $s e$, are not the focus of this paper. ${ }^{4}$ Rather, the histories analysed in this instance focus predominantly on the political environments within South Australia, in as much as they influenced and shaped the subsequent production of ideals of the 'good community' in the Golden Grove Development.

This story is structured around the junction between welfarist and neo-liberal techniques and modes of government. While there is no clearly defined division between the two, the framework adopted is useful to highlight some of the shifts and resultant mutations within liberalism, from welfarism to neo-liberalism. The paper begins by establishing the framework for the analysis. This is followed by an outline of the Australian Federal and South Australian political context of the 1960s and 1970s. A key political incentive at this time was the establishment of Land Commissions as agents of a predominantly welfarist Government. It was within this context that the Golden Grove Development was initially conceived. However, with the demise of welfarism in Australia and the strengthening of neo-liberal modes of government, the involvement of the State and Federal Government in urban projects was curtailed. The ideals of community that were intrinsic to the initial welfarist Golden Grove Development plans were reinterpreted under increasingly neo-liberal regimes and reproduced to align with capitalist market trends and to secure private enterprise objectives. Consequently, the completed development depicts a polarized landscape, both within the development and within the wider suburban area. ${ }^{5}$

\section{Establishing the framework}

Ideals of community are often popularized in response to the 'ills' of modernization - rapid technological changes and the impacts of globalization - which are frequently blamed for the demise of gemeinschaft relationships. ${ }^{6}$ The focus on ideals of community in the discourses of the Golden Grove Development, and with many other such developments worldwide, ${ }^{7}$ was perhaps in response to this largely perceived loss. The Golden Grove Development discourses privilege specific lifestyles, values and ideals that are commonly associated with 'the Australian Dream' (see Figure 2); a dream which equates 'the good life' with home ownership in the suburbs. Suburbia as 'the Australian Dream' emerged in nineteenth century industrialization, at which time cities received much of the negative rhetoric - unhealthy, overcrowded and unnatural. In contrast, suburbia was pictured as all that pertained to 'the good life' - healthy, open, family lifestyle and rural or gemeinschaft relationships. The identities and subjectivities attributed to suburbia and 'the Australian Dream' are frequently founded on largely imaginary, historic concepts of 'the good life'. I argue that the developers of the Golden Grove site appropriated these historically established identities and subjectivities in order to produce 'good (neo-liberal) communities', comprising disciplined, docile and self-regulating subjects; hence my use of the term ideals of the 'good community'.

Many planning discourses have sought to produce ideals of community. Within these discourses 'community' is often constructed as a phenomenon that is producible through and by the built landscape. This is particularly evident in the discourses of the Golden Grove 


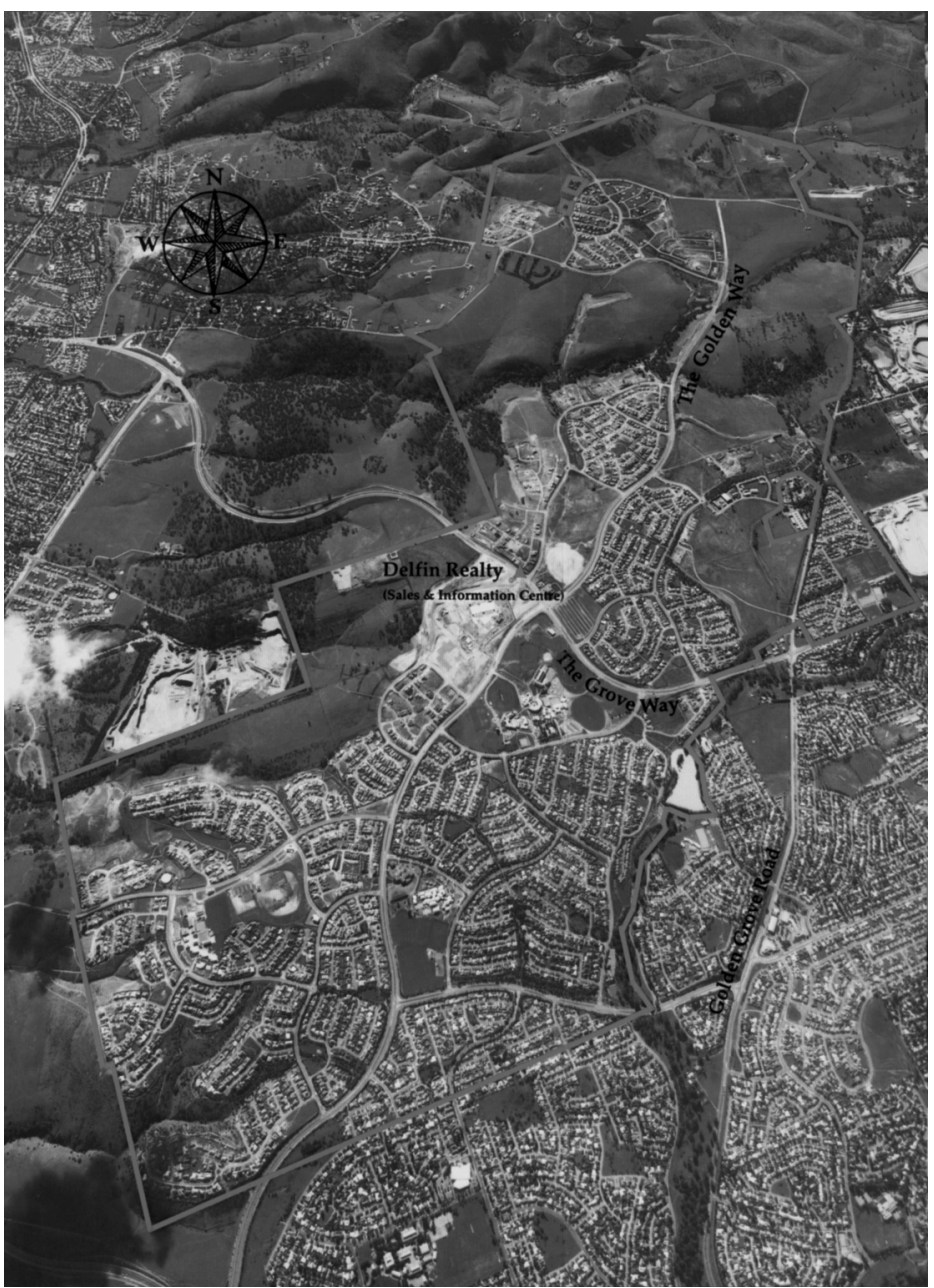

Figure 2. The physical landscape of the Golden Grove Development suggest particular lifestyles and values, encapsulated in notions of the 'Australian Dream', that resonate with ideals of the 'good life'.

Development. Key Golden Grove Development planning, marketing, development, legislative and business texts pointed to the production of particular ideals of community and stipulated the practices and techniques by which these ideals were to be realized. 9 However, 'community' is not a physical or tangible 'thing' that can be planned for and known. Ideals of community are complex and involve deeper structures than casual encounters in a public place or concepts of mutual pride and a shared identity. They may have little relevance to a bounded locality, a particular type of architecture or spatial expression, and they may not involve verbal or visual interaction. The values and meanings attributed to ideals of community are not fixed in time nor are they universally 'true'. Ideals of community are conceived, influenced and produced by many and various contemporary and localized forces which 
continually fluctuate and are subject to change. This argument is supported by many 'building community' histories that record the failed attempts by many planners and architects to create 'good community' subjects through the implementation of particular planning techniques and practices.

Both the social (ideals of community) and the physical landscapes of the Golden Grove Development were produced in a political environment that was characterized by a re-territorialization of government, from a welfarist to a neo-liberal governmental framework. This was not a smooth transition from one form of government to another. Rather, following Pauline McGuirk the transition was characterized by 'a series of complex and overlapping strategies that produce[d] a hybrid form of governance', where outcomes were not guaranteed and resistance occurred. ${ }^{10}$

Both welfarist and neo-liberal rationalities are embedded within liberal discourses. Welfarism did not necessarily relate to new 'problems'. Rather existing everyday conditions were often taken up and problematized by experts with the aim to standardize and regulate the conduct of individuals, with the objective to maintain or enhance the well-being of the population and the economy (see Whitlam Government - next section). Through education, planning and advising practices, experts position themselves as agencies that lay claim to "the power of truth' and from this vantage point they offer to teach people techniques to 'manage better, earn more, bring up healthier or happier children and much more besides'. ${ }^{11}$ Notwithstanding, welfarist planning processes were technocratic and interventionist and they did not meaningfully address their raison d'entre - social inequality.

The mutation from welfarist to neo-liberal modes of government are indicated by (among other things) a belief in a free market political economy: deregulation, privatization and by the apparent withdrawal or abstinence of the government from intervening in everyday life. The diffusion of state power was superficially, more democratic, economic, efficient and effective. The passing of responsibility onto private enterprise was rationalized in terms of economics and efficiency - involving less government - and thus, apparently, achieving cost savings. That is, the government is not seen to be directly intervening into areas where private enterprise experts are believed to be better equipped to do the work quicker, more effectively and more efficiently. Following Mitchell Dean, this splintering of government was partly a reaction to welfarism, which was criticized by many Marxists and feminists for producing capitalist outcomes and propagating gender divisions. Dean argues that 'The welfare state was understood as a paternalist mechanism of social control, relying on uniform provision that is bureaucratic, hierarchical, sometimes coercive and oppressive, and often unresponsive to the needs and differences of individuals and communities'. ${ }^{2}$

As already stated, under neo-liberalism, the activities and policies of the government - and specifically in this instance planning policies - are aligned with market forces. Brendan Gleeson and Nicholas Low ${ }^{13}$ argue that neo-liberalism is a model of economic growth that upholds the free market as the 'best mechanism for organizing affairs and even social life'. Neo-liberal planning processes that are aligned with market forces offer limited opportunities for meaningful public intervention, as demonstrated in the processes leading up to the signing of the Gold Grove Indenture Ratification Act outlined in the latter part of this paper. Planning under neo-liberal government agendas, following Gleeson and Low, ${ }^{14}$ is characterized by competition, deregulation and privatization. All three characteristics are evident in the latter planning techniques that saw the Golden Grove Development become a reality. It is these three 
characteristics that frame the analysis of the suburban production processes in the 'building' of a Golden Grove 'community', as outlined in the remained of the paper.

\section{The federal and state political contexts}

Development of the Golden Grove site emerged at a time in Australia when there was a population boom and a growth in low-density suburban housing. Clive Forster and Murray McCaskill write of South Australia, and by implication Australia in general, 'manufacturing, immigration and suburban sprawl formed a seemingly irresistible self-perpetuating nexus'. ${ }^{15}$ This pattern of urban growth was formalized in the 1962 Adelaide Metropolitan Development Plan (MDP). The MDP was the first attempt since the 1930s to implement South Australian planning policies that were proactive and visionary. As with other Australian metropolitan planning strategies of the day, the Adelaide plan was primarily concerned with development on the urban fringe and it identified large tracts of rural land for future residential development. The Golden Grove Development site was one of these identified tracts of rural land. By 1965, however, the MDP had not been legislated.

Between 1965 and 1967 the South Australian Government had three Premiers and a change of political parties, from Liberal and Country League to Labor (1965) and back to Liberal and Country League (1967). With the return of a Liberal Government and with pressure from the opposition, the previously dormant 1962 Metropolitan Development Plan for Adelaide was finally adopted by the passing of the Planning and Development Act (1967). The plan subsequently remained the official framework for urban planning throughout most of the 1970s and some argued its influence was still significant during the 1990s. ${ }^{16}$

The early 1970s saw Labor win office at both Federal and State level, with Edward Gough Whitlam as the prime minister of Australia and Don Dunstan as premier of South Australia. The Whitlam Labor Government was the first Federal Labor Government in power in 23 years. Although the Australian Labor Party was not to retain office for long (December 1972-November 1975) the techniques of government put in place by the Whitlam Government expressed particular rationalities which were to have a profound influence on many of Dunstan's early policies and achievements. Whitlam advocated a welfarist technique of government; a form of government that emerged after the World War II in response to rapid population growth, a shortage of housing, the necessity for infrastructure (roads, sewers, electricity, etc.) and a lack of schools, hospitals and other public institutions. The welfarist goals of the Whitlam Government included 'collective welfare through rational suburbanization, and the protection of the most vulnerable through a modest public housing sector'. ${ }^{17}$

Urban planning under Whitlam was placed within a social context; one based on collective responsibility rather than individual obligation. Whitlam argued that quality of life was dependant on public bodies - police, schools, hospitals, planning authorities, etc. - and that issues of inequality were the concern of the Government. ${ }^{18}$ The Whitlam Government allocation of a substantial budget to urban planning and a major portion of this funding was to entice State Governments into developing an urban agenda, by giving them access to Federal grants and loans. As a means of achieving the urban goals of Federal Government, State Governments were encouraged to develop new cities in rural areas and to establish 'land commissions to support public land development on the fringes of capital cities'. ${ }^{19}$ 
The call for the establishment of Land Commissions in the early 1970s and social interventionist policies in urban projects were not unique to the Australian Federal Government. At a similar time the National Government of Japan introduced the National Land Planning System, which allowed the Japanese Government to intervene and regulate the land and housing markets in much the same way as the Australian Land Commissions were intended to do. Specifically, the National Land Planning System focused on fully planned residential developments on the outskirts of major cities (as did the Land Commissions). ${ }^{20}$

Whitlam's three-year term in office ended in 1975 with many of his urban policies not fully realized. The incoming Fraser Liberal Government had little interest in urban issues, which were seen as the responsibility of the States. The aim of the Liberal Government was to reduce public spending and focus on private enterprise initiatives. The end of the Whitlam Labor Federal Government and the loss of Federal funds and an urban agenda were to have serious repercussions for the South Australian Dunstan Labor Government.

The South Australian Dunstan Labor Government (June 1970-February 1979) was the only State Labor Government in office for the full duration of Whitlam's reign. As such South Australia was in a position to benefit substantially from Federal policies, grants and incentives. The Dunstan Government, in keeping with the Whitlam Federal Government policies, adopted particular welfarist techniques of government, where urban planning was considered as 'social intervention', and where:

Equity and quality of life, rather than efficiency, became the major planning concerns. ... A sense of optimism prevailed concerning the ability of 'planning' - broadly defined as public intervention designed to shape urban growth and change - to improve the quality and equity of life in Australian cities. ${ }^{21}$

\section{The South Australian Land Commission}

By the time Whitlam Labor Government was ensconced in power the South Australian Dunstan Government was in a position to formalize the embryonic South Australian Land Commission (SALC). This new governing body offered the Dunstan Government an opportunity to implement the urban planning, welfarist goals espoused by Whitlam. These were new and innovative policies that would ensure a multi-disciplinary, proactive approach to planning and development.

Dunstan's proposals were not only in response to Federal incentives, they were also informed by the relatively low levels of unemployment and the rapid population growth experienced in South Australia at the time. As a result of these factors, existing stocks of residential land in Metropolitan Adelaide had begun to dwindle, land values had escalated and private developers stood to make enormous profits. One of the primary tasks conferred on the new SALC was the control and stabilization of land prices. This was to be achieved by purchasing and then releasing land to the private sector in a steady and controlled manner. In addition, the SALC was authorized to achieve 'comprehensive and orderly urban development' and to ensure that land value increments, gained from the rezoning of rural land for urban use, would be reinvested in 'the community'. ${ }^{22}$ Although the SALC had its genesis in welfarist modes of government, in practice it embodied early neo-liberal tendencies as outlined below.

The establishment of the SALC impacted upon and undermined the role of the South Australian Housing Trust (SAHT), which had previously held the role of State land bank and 
developer. The SAHT had primarily been concerned with the provision of houses for workingclass Australians to purchase. The South Australian Government had previously been a strong advocate of the SAHT, as a means to provide low cost housing for people in the workforce. Cheap accommodation was rationalized as a means to keep wages to a minimum and low wages were given as an incentive for large industries to invest in South Australia, ultimately, to the benefit of the South Australian economy.

The SALC had two critical advantages over the SAHT in support of its role as State land bank and developer. Firstly, the newly formed commission was backed by approximately $43 \%{ }^{23}$ of the funds offered by the Whitlam Government and secondly its influence was extended through powers of compulsory acquisition. It was primarily because of these two factors that the SALC had the ability to compulsory acquire and consolidate the rural parcel of land that was proposed in the 1962 Metropolitan Development Plan. Although some property owners and Government critics opposed the land acquisition and the loss of fertile farming land to urban development, in the end, the Government achieved its objective. The purchase 15 of the land was based on the rationale that, given the forecast population growth and the dire shortage of existing land stocks, it was in the public interest that the site be developed.

With the dismissal of the Whitlam Federal Labor Government and the election of the Fraser Liberal Government in 1975, the proposed development of the rural land was under threat. As suggested earlier, one of the key factors enabling the SALC to pursue development of the site was the availability of substantial Federal funds. The Fraser Liberal Government did not have the same commitment to urban policies and consequently Federal money for urban projects was stopped. This left the SALC with a substantial debt.

25 Early plans

As already stated, the inception of the Golden Grove project took place in the early 1970s and was framed, in part, by welfarist rationalities. The brief for the initial feasibility study for the Golden Grove site called for alternative design concepts for a fully serviced residential area that would ultimately improve the standard of living for all South Australians. The opportunity

30 to pre-plan, control and coordinate such a large area of broad acre land was promoted as offering 'a fine opportunity to improve substantially upon the general pattern of urban development'. ${ }^{24}$ The planning techniques for the Golden Grove site were to break with traditional blueprint or end state models. From the outset the planning of this parcel of land was to be and in practice was - open ended, where outcomes were not predicated or set in concrete. 35 Planning decisions were (to be) of a general nature, based on market trends, guidelines and staging plans, and open to review through processes of annual forecasting and monitoring. This break with interventionist welfarist approaches to planning, instigated and backed by the SALC, paved the way for progressively finer tuned, neo-liberal modes of government.

By late 1974 the SALC had appointed the consultants Tract S.A to produce a Development Plan for the Golden Grove site. By January 1975, Tract S.A had submitted an interim report and by March the following year the 'Comprehensive Development Plan: Modbury-Golden Grove' was completed. This document stated five initial (welfarist) social and physical planning objectives: flexibility, efficiency, freedom of choice, social equity and likely acceptability; objectives which were reinterpreted and reproduced in varies planning schemes for the Golden Grove project as discussed later in this paper. 
Throughout the project proponents argued for the planning of the Golden Grove site to differ from other Australian suburbs. The Golden Grove Development was perceived as an opportunity to set new standards in urban development that would establish benchmarks for suburban planning practices. The planning practices that were to comprise the new development were not only to provide 'good environments for residents but [also give] a lead to private and public developers' both locally and nationally. ${ }^{25}$ To achieve this aim a 1977 marketing brief propositioned that a 'total community' be marketed through uniqueness of planning and built form. ${ }^{26}$

The 1976 Golden Grove Structure Plan called for a 'cohesive community' to be created primarily through the conjoining of new Golden Grove Development and existing Council wide services: sewer, electricity, water, gas, health, education and social. ${ }^{27}$ This included the construction and realignment of new roads together with walking trails and open space zones as a means to 'integrate' the Golden Grove site, both physically and socially, with the surrounding metropolitan area. These planning techniques were the ones which were not generally found in South Australia prior to this time. Instead, developers usually subdivided greenfield sites and developed and sold allotments in a fragmented, piecemeal fashion with little or no attention to the provision of services, roads and green spaces. Previous South Australian fully planned community developments and new towns such as Colonel Light Gardens (developed from 1921), ${ }^{28}$ Elizabeth (inaugurated 1955) ${ }^{29}$ and Monarto (a proposed new town initiated in the early 1970s with funds from the Whitlam Government and which never proceeded $)^{30}$ were primarily planned as satellite towns rather than being physically incorporated into and extending existing metropolitan infrastructure patterns.

Nonetheless, it is important to note that many of the planning techniques and practices of the Golden Grove Development resemble earlier fully planned community developments such as Colonel Light Gardens, Elizabeth and Monarto. More specifically, the direct antecedent of the Golden Grove Development was the fully planned community suburb - situated approximately 17 kilometres west of the Adelaide CBD - of West Lakes. West Lakes (1969), like the Golden Grove Development, was developed as a joint venture between the Development Finance Corporation (later to become the Delfin Property Group) and the South Australian Dunstan Labor Government. Although it is not within the scope of this paper to elaborate on the similarities and differences between these models, the genealogy of the Golden Grove Development is significant and offers opportunities for further research.

The values and rationales encapsulated in the 'community' objective of the Dunstan Government - mainly the production of a healthy, good, moral suburban subject and lifestyle - were not the ones commonly associated with suburban living in the 1970s. One of the principal aims of the (welfarist) Australian Federal Labor Government in the early 1970s was to address the perception that many suburban areas suffered from a lack of amenities; a factor which the Federal Government aligned with social and place depravation. The perceived lack of attachment to place was highlighted in the 1976 Golden Grove Structure Plan which stated that suburban areas were 'often characterized by monotonous planning and dreary architecture .... ${ }^{31}$ In addition the authors of the Structure Plan highlighted the following 'problems' of many new suburban developments: lack of identity, lack of belonging and pride in the local area and lack of housing choice. In contrast to the largely perceived images of many existing suburbs, the emerging Golden Grove Development lifestyle was to present a fresh new image of suburban living. The ills of suburbia were to be avoided 
through innovative planning and design and through the provision of adequate, appropriate and economic infrastructure.

To ensure the planning and development process for the Golden Grove parcel of land would be quick, easy and reliable, the Tea Tree Gully (Golden Grove) Development Act 1978 was passed in April 1978. The existing statutory planning system was considered 'as being too rigid, negative and time consuming, particularly in relation to the development of broad acres, ${ }^{32}$ To address the criticism of the existing planning system, the Tea Tree Gully (Golden Grove) Development Act, 1978 conferred development responsibility (for the Golden Grove parcel of land) onto the SALC. The Honourable Hugh Hudson (Minister for Planning) told 10 parliament that the act was a 'means of trying to ensure a more effective, flexible and quick method of development control'. ${ }^{33}$ In effect, this would allow the planning and development of the Golden Grove site to bypass the existing supposedly inadequate and inappropriate planning system. The Act also revoked the planning powers of the Tea Tree Gully Council and the State Planning Authority and replaced the existing planning regulations with development principles.

By 1979 a further development study report for the Golden Grove parcel of land had been produced along with 'Draft Development Scheme No. 1'. This scheme was a consolidation and reworking of previous plans, reports and related documents and it was to form the basis for development control. The scheme consisted of objectives and responsibilities for development,

20 a feasibility plan and proposals for the first stage of development. The Development Scheme required ministerial approval before it could be implemented. However, by the time of the November 1979 election, the Labor Government Minister for Planning had not yet signed the document and the future of the Golden Grove Development was thus placed in abeyance. Despite the dispersal of governmental authority, in an attempt to govern effectively and

25 efficiently, the failure of one person to act (to sign the document) meant the entire project was put on hold.

The Dunstan decade was at its end. Dunstan, with the initial assistance of substantial Federal support, had contributed to putting South Australia at the 'cutting edge of Commonwealth land and housing policy, ${ }^{34}$ The SALC owned 35\% of land on the edge of Metropolitan Adelaide

30 (approximately 5000 hectares, $37 \%$ of which was zoned for future development) and was retailing $25 \%$ of all new residential allotments in the metropolitan area. ${ }^{35}$ It was primarily because of the extent of development being undertaken by the SALC that many private developers sought the support of Liberal politicians to oppose the agency and ultimately the Dunstan Government. Dunstan resigned in late 1978 and the Corcoran Government held office until the November 1979 election, which heralded into power the Tonkin Liberal Government.

\section{Shifting practices}

The new Tonkin Liberal Government sought the 'continuous facilitation of urban growth and change, rather than the production and implementation of physically defined plans ${ }^{3}{ }^{36}$ By early 1981 the Government had published, and put on public display, Development Regulations and Development Directions Nos. 1, 2 and 3, covering the first stage of development - an area of approximately 405 hectares, housing a population of 10,000-12,000 in approximately 3400 dwellings. ${ }^{37}$ Once approved by the minister, the Directions would become legislation that would guarantee the implementation of the Development Scheme. This planning procedure 
was markedly similar to the planning process which the Dunstan Government sought to achieve with the Tea Tree Gully (Golden Grove) Development Act 1978. The aim of the Tonkin Government - to facilitate development - was not dissimilar to that of the Dunstan Government. The Tonkin Government, however, sought to withdraw from the urban planning and development arena, principally through an electoral promise to reassess the role and structure of the SALC. The withdrawal of the Tonkin Government from the planning process and the attempt to deregulate the planning procedures through development regulations and directions are in line with Gleeson and Low's three characteristics of neo-liberalism outlined at the beginning of the paper: competition, deregulation and privatization.

The role of the SALC as developer, in addition to its principal role as land bank, was criticized by many in the building industry because it was perceived as an organization that restricted and inhibited private enterprise developers. Critics argued that the principal role of the SALC was negated by its role as developer. In addition, the SALC was accused of spending a lot of the Commonwealth resources on development which private enterprise developers could, seemingly, do just as well and just as cheaply. The Urban Development Institute and the Housing Industry Association, in particular, lobbied for the restructuring of the SALC on the grounds that its policies and practices were ill advised, the SALC would not sell any of its land to private enterprise developers and thus land and housing market processes were adversely affected, and the mounting debt incurred by the SALC would necessitate a substantial increase in land prices. ${ }^{38}$ The primary reason for the establishment of the SALC in the early 1970s was to regulate and control the cost and release of land because many private enterprise developers were, allegedly, making enormous profits and were unable to keep up with the demands for new land and housing. Much of the negative criticism of the SALC, however, was not entirely justified. Some private enterprise developers had previously sold land to the SALC and the SALC had also employed a number of private enterprise experts as consultants, to carry out planning and development projects.

To address the concerns of the private development industry, in late 1981 the Tonkin Government restructured the SALC and renamed it the South Australian Urban Land Trust (SAULT). SAULT was to remain under the control and direction of the Government; however, its role was to be primarily that of a land bank, with no powers to purchase or develop further land. The Golden Grove parcel of land acquired by the SALC and now owned and administered by SAULT, was no longer considered as a Government project that afforded 'a fine opportunity to improve substantially upon the general pattern of urban development.${ }^{39}$ Instead the Tonkin Government proposed to sell the consolidated land to private investors or developers, leaving the Government with no direct involvement in the project.

By rationalizing land and housing market processes as quasi-natural, the Tonkin Government in effect, shifted the focus of the goals espoused by the Dunstan Government. While quality and equity of life remained paramount objectives in the proposals for the Golden Grove Development, these objectives were endowed with economic values. As such, equity and quality of life became affordable only to those individuals who had the means and the ability to participate in land and housing market processes. The reliance on market processes, thus, perpetuates social polarization, as quality of life is available only to those who can afford it. The physical and social environments of the Golden Grove Development, under the control of private enterprise developers and governed by market processes, suggest patently different landscapes to those depicted by the interventionist techniques of the SALC. 
To stimulate private enterprise interest in the planning and development of the Golden Grove site, in December 1981, the Tonkin Government prepared the Golden Grove prospectus and advertised a public call for expressions of interest. The prospectus outlined arrangements whereby, a private developer would progressively purchase the land owned by SAULT at contemporary market values. The involvement of SAULT in the planning and development of the Golden Grove site would be limited to its representation on a development committee. The developer would have the authority to release land and develop housing in accordance with market forces, backed by legislation that would limit intervention. By the close of registration early the following year, three submissions had been received.

\section{Mark two}

Late in 1982 events again took a turn with the re-election of a South Australian Labor Government under the leadership of John Bannon, followed closely by the election of a Federal Labor

15 Government under the leadership of Bob Hawke. The South Australian Government looked once again to be in a position to benefit from Federal incentives. In the early years though, the Hawke Labor Government showed little interest in urban planning outside of making the planning process simple and economizing on public services to ensure Federal Government policies on affordable housing succeeded. ${ }^{40}$ The Bannon Government, on the other hand,

20 indicated its commitment to planning, coordinating and funding community development in new areas. In some respects the objectives of the Bannon Government recall the early welfarist techniques of the Dunstan era. The Bannon Government, however, adopted a distinctly different style of government from its Labor predecessor, advocating techniques of government that reflected and re-inscribed the neo-liberal rationalities of the Tonkin Liberal Government.

The predominant urban planning policies and practices of the three successive South Australian Governments, from the early 1970s through to the late 1980s, illustrate the gradual and mutative shifts away from welfarist techniques of government. The Bannon Labor Government sought a different role for SAULT from that of the SALC under the Dunstan Labor Government and the role of SAULT under the Tonkin Liberal Government. Initially,

30 the SALC was the sole agency invested with the authority to plan and develop the Golden Grove site. With the restructuring of the SALC, SAULT was instructed to sell the Golden Grove parcel of land and confer development initiatives onto private enterprise developers, leaving the Government with little authority to intervene. With the election of the Bannon Government, SAULT was re-invested with a limited capacity to purchase and sell land. Given 35 this resumed role, in 1983 SAULT commissioned a report from consultants Northage and Associates to highlight potential development arrangements and alternatives for the Golden Grove site. The report was to reflect the policy objectives of the Bannon Government thereby ensuring the provision of reasonable land prices, a range of housing types, a high level of design, the inclusion of 'community infrastructure' - and give the Government the ability to intervene and regulate planning practices. ${ }^{41}$ While the Bannon Government did not confer upon SAULT the extended influence of its predecessor, the SALC, it did allow SAULT the opportunity to take an active role in the planning and development of the Golden Grove site. To facilitate this role, Northage and Associates suggested SAULT enter into a joint venture partnership, legislated by indenture, with a single, major private enterprise developer for the life of the project. 
Following the advice of the consultants, the contract mode chosen by the Bannon Government for the development of the Golden Grove site was that of a joint venture. This partnership was to be between the State Government and a private enterprise developer - as joint planners and developers - and the Tea Tree Gully Council - as a supportive agency. An important influence on the choice of this development arrangement was the 1969 joint venture between the Development Finance Corporation and the Dunstan Labor Government for the development of West Lakes. The choice of a joint venture partnership, in effect, compromised neo-liberal rationales of the Tonkin Government while maintaining a quasiinterventionist role for SAULT.

In December 1983 the Bannon Government selected the Delfin Property Group as the preferred joint venture partner.

\section{The indenture}

Upon selection, Delfin undertook to work with a subcommittee of SAULT to prepare a feasibility analysis which would form the guiding principles for the proposed indenture documentation, including the joint venture partnership. The feasibility study was to be presented to the Minister for Environment and Planning, Don Hopgood, by the end of March 1984. In late April the presentation was made and the minister suggested the scheme be presented to cabinet early the following month. By this time, Delfin had produced the first structure plan (see Figure 3) and agreement had been reached on administrative matters, land ownership, land price, payment methods, sales procedures and the inclusion of public housing.

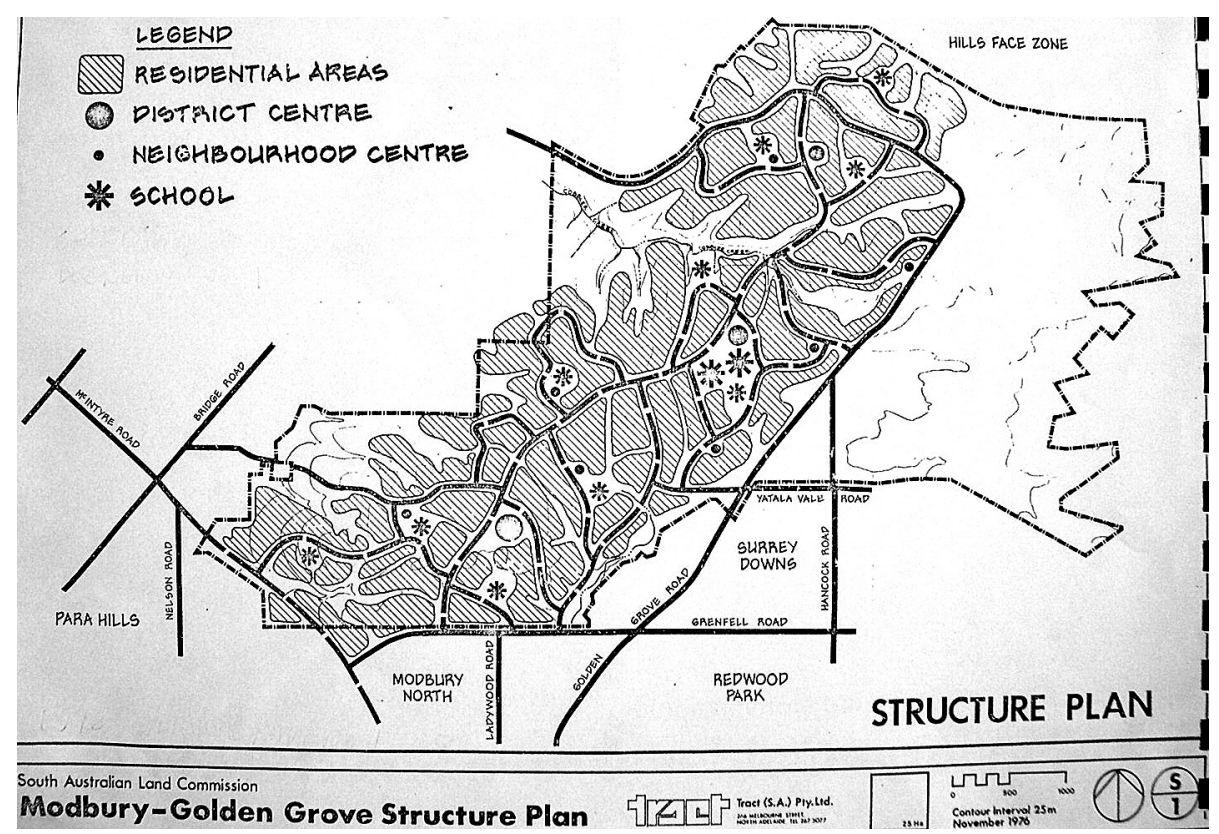

Figure 3. A simplified early Golden Grove Development structure plan redrawn by the author. 
Given the extent of the proposed development and the large sums of money involved, the Bannon Government announced the formation of a review group in July 1984. The purpose of the review group was to reassess the terms and agreements proposed in the feasibility study to ensure the objectives of the Bannon Government were, 'adequately reflected' and the financial proposition was 'reasonable from a Government viewpoint'. ${ }^{42}$ The members of the review group were familiar with the objectives of the Bannon Government and the histories of the Golden Grove parcel of land. Review group members were thus in a position to ensure political objectives were re-inscribed and re-produced in the terms and agreements of the proposed joint venture partnership and related indenture documentation. In the final report to

10 Minister Hopgood, the review group recommended 'certain changes ...; the principal purpose of which was to ensure that government's social aims and objectives, with regard to Golden Grove, become the focus of the joint venture' ${ }^{43}$ The Government accepted the report without alteration.

With the approval of the Tea Tree Gully Council, the path was cleared for the drafting of necessary legislation that would ratify the indenture and formalize the joint venture partnership. While the Council was given the opportunity to review the terms and agreements of the proposed indenture, they were not given any legal capacity to change, intervene or influence planning and development. This process of limited consultation, which limited opportunities for meaningful public intervention, is characteristic of the neo-liberal planning techniques outlined at the beginning of this paper. Council did, however, give its informal approval of the joint venture partnership and the proposed planning and development strategies for the Golden Grove parcel of land.

The joint venture agreement was finally signed on 30 October 1984 by SAULT and the Delfin Property Group. Due to the feasibility study review and the subsequent negotiation 25 process, the signing of the joint venture agreement was approximately four months later than originally forecast in the feasibility study. The original date set for the first land release October/November 1985 - was, however, not changed. This put pressure on the developers to complete documentation and to make all necessary arrangements to ensure development began on site as scheduled. On account of the short time frame, the bill to ratify the indenture

30 was introduced in parliament on the same day the joint venture agreement was signed. This allowed only a matter of hours for the SAHT to assess and sign off their approval of the joint venture arrangements, which committed them to purchasing $25-30 \%$ of the total number of allotments.

Although the joint venture documentation had been well considered by the Bannon Government, not everyone was in agreement with the proposed partnership. Blair Badcock (an urban and housing researcher based in Adelaide at the time) suggests that the indenture favoured private enterprise developers, did not sufficiently safeguard public interests, created a potential conflict of interest between public and private enterprise aims, established a monopoly, and undermined the role of SAULT to stabilize land costs. ${ }^{44}$ These concerns arose 40 out of the neo-liberal governmental framework of the Bannon Government. It was not surprising then, that the bill to ratify the joint venture partnership did not pass through parliament on the day it was introduced. Instead the Government elected a committee to investigate the joint venture arrangements and structure. During the four-week investigation period, various people were called as witnesses before the committee and a nominal advertisement was placed calling for interested persons to express their concerns. Given the rejoinder of the committee and the 
lack of public response to the enquiry, Minister Hopgood recommended the bill proceed through parliament without amendment. The bill was passed, unchanged, on 20 December 1984 and the Golden Grove (Indenture Ratification) Act, 1984 was enacted. The neo-liberal techniques of government of the Bannon Government, thus, established the precedence for the social and physical future of the Golden Grove Development. The ratification of the indenture prompted outrage by some, in the belief that the Bannon Government had granted Delfin a virtual monopoly over Government owned land and the sanction to make excessive profits. ${ }^{45}$

\section{Ratification rationales}

The bill to ratify the joint venture consisted of three sections: the joint venture agreement; a management agreement; and the indenture.

The joint venture agreement set out the cost and profit sharing arrangements, land costs and land release procedures. All costs, including land purchases, project management fees and advertising, and profits were to be shared equally by the partners. Ownership of the land was to remain with SAULT until sold to the developers at a fixed price. By project completion SAULT was to receive 20 million Australian dollars for the land. ${ }^{46}$ This arrangement was one of the key concerns of many who opposed the joint venture legislation because the Bannon Government was handing over public land to private enterprise developers at an extraordinarily low cost.

The agreement also included the structure of a joint venture committee which was to govern planning, marketing and development. The indenture required the committee to manage the Golden Grove Development in accordance with the stated Primary Covenants; the first of which is the most relevant in this instance:

Delfin and SAULT each hereby covenant that ... they shall progressively develop the land ... in accordance with the Joint Venture Agreement and in such regard they do each separately covenant that they shall discharge these obligations one to the other and pursue their common purpose in an ethical and commercial manner at all times consistent with the Paramount Objectives set forth in the Third Schedule. ${ }^{47}$ (my emphasis)

This covenant was included in response to the advice given to the minister by the initial feasibility study review group, with the assumption that the objectives of the Bannon Government would be upheld and at the same time the objectives of private enterprise would be supported. As such, ethical practices of government are tied to market processes and ascribed a commercial value. This suggests that the developers would only pursue those ethical practices that offered good economic returns.

The joint venture committee was also vested with the authority to initiate Supplementary Development Plans, which could (in accordance with neo-liberal characteristics) be submitted directly to the minister for approval without necessarily consulting the Tea Tree Gully Council or the public.

The joint venture agreement stipulated that the committee comprise seven members: three to be nominated by the State Government, three by Delfin plus an independent chair. The members of the committee were not unknown to each other; the independent chair, in particular, was well acquainted with the Delfin representatives, two of whom had also been party to the drawing up of the indenture documentation. In the selection of the independent chair, by both the Bannon Government and Delfin, the neo-liberal principles and goals for the development 
of the Golden Grove site were ensured. This political (neo-liberal) process of selection ensured that the goals of the Government would be achieved in line with market forces.

The second document, the management agreement, named Delfin Reality as being the sole real estate agent and Delfin Management Services as the consultant responsible for development - planning, design, landscape and engineering - marketing and project management. The management agreement listed the obligations under which the project was to be developed and marketed; that is, in accordance with the primary covenant stated earlier. The agreement also stipulated the fee to be paid to Delfin Management Services, by the developers, including the employment of a project manager. Delfin Management Services were obliged to submit, to the

10 joint venture committee, a yearly business plan and marketing reports, plus update reports as and when required. The joint venture committee would then monitor, guide and control planning and development in accordance with the Delfin Management Services plans and reports. The legislated employment of Delfin Management Services and Delfin Reality in the creation of the Golden Grove Development suggests that the private enterprise equity partner ostensibly represented the dominant authority. In practice, this argument was supported as the joint venture committee, generally, endorsed the project business plans without requiring any significant alteration to them.

The third and crucial document was the indenture, which once ratified by parliament would ensure the joint venture and management agreements were binding. The indenture included 10 Paramount Objectives (see following section) which the committee were to enforce, and detailed the roles and commitments of the developers, the State Government and the Tea Tree Gully Council.

In keeping with the original planning objectives of the Golden Grove Development flexibility and facilitating a quick, easy and reliable planning and development process - the indenture gave the developers the authority to bring into effect planning practices that did not require Council or State approval. The influence of Tea Tree Gully Council and the State Planning Authority on subdivision design was limited to engineering and the provision of services; they had no say in the overall design, layout of allotments or development control. In addition, the indenture was structured, in keeping with previous proposed models, to allow the 30 greatest opportunity for building compliance. The entire development area was zoned residential, with the exception of a small area adjacent to an existing sand mine which was zoned light industrial, and all forms of residential development were considered as complying. This process facilitated speedy financial returns, as more allotments could be sold, approved and developed in a shorter time frame. It also gave the developers and Delfin Management

35 Services in particular, a quasi-monopolistic role in the physical and social creation of the Golden Grove Development.

\section{Paramount objectives}

40 Values relating to the five initial welfarist inspired 1976 Development Plan objectives flexibility, efficiency, freedom of choice, social equity and likely acceptability - were reinscribed and reinforced throughout the early planning phases (1976-83) of the Golden Grove site. These five objectives were then reiterated, reinterpreted and finalized as the 10 Paramount Objectives legislated in the 1984 indenture. In summary, the Paramount Objectives are: ${ }^{48}$ 
(1) to develop the land in accord with State Planning policies and to ensure new infrastructure co-joins neighbouring areas;

(2) to provide a range of accommodation types and tenures at affordable prices;

(3) to sell between $25-30 \%$ of the total number of allotments to the SAHT for public housing and to disperse SAHT allotments throughout the development;

(4) to release land concurrent with the completion of infrastructure;

(5) to adopt practices which minimize land and housing costs to prospective residents within the bounds of prudent commercial and land development practice;

(6) to develop a 'safe pleasant and convenient' area and to include the provision of community facilities and services;

(7) to produce a community development programme;

(8) to develop the Development Area in a manner sympathetic to the environmental features of the area;

(9) to establish an 'efficient and effective form of planning and development control'; and

(10)to engage a range of residential building companies to work on the site.

The legislation of the Paramount Objectives represented a neo-liberal guarantee for the planning and development of a more or less 'authentic' (in contrast to post World War II suburban planning practices) suburban environment. That is, the Paramount Objectives embraced concepts of flexibility, efficiency, freedom of choice, social equity and likely acceptability - concepts tied into the production of particular ideals of the 'good community' - primarily through offering the autonomous individual the 'freedom' of choice within a capitalist market. Ironically, the Paramount Objectives evolved out of a form of guarantee against profit-mongering private enterprise practices, social exclusion and polarization. In the latter years of the development it was these identity markers that became synonymous with the new suburban area (see Figure 4), neo-liberal markers which were largely produced with reference to the Paramount Objectives.

Essentially, the Paramount Objectives established sets of rules by which and through which the developers could 'build' a Golden Grove 'community', in accordance with particular neoliberal ideals of the 'good community'. The Paramount Objectives were instrumental strategies for securing both the social (ideals of the 'good community') and financial successes of the Golden Grove Development. On the one hand, the Paramount Objectives obliged the developers to implement planning techniques and practices that would manifest both social and physical residential environments that were 'diverse', 'pleasant' and 'safe'. On the other hand, they required the developers to develop suburban landscapes that would foster and reflect risk minimization techniques; in particular where the risks were attached to difference, deviance and investment values (see Figure 5). Ideals of community become complicit in re-inscribing neoliberal forms of government which compartmentalize the suburban landscape into pockets of the included 'us' and the excluded 'other'.

\section{Concluding comments}

The eventual emergence of the Golden Grove Development was a by-product of both welfarist and neo-liberal modes of government. During the 1970s and 1980s the emphasis given to social planning practices, by the various South Australian Governments, fluctuated 


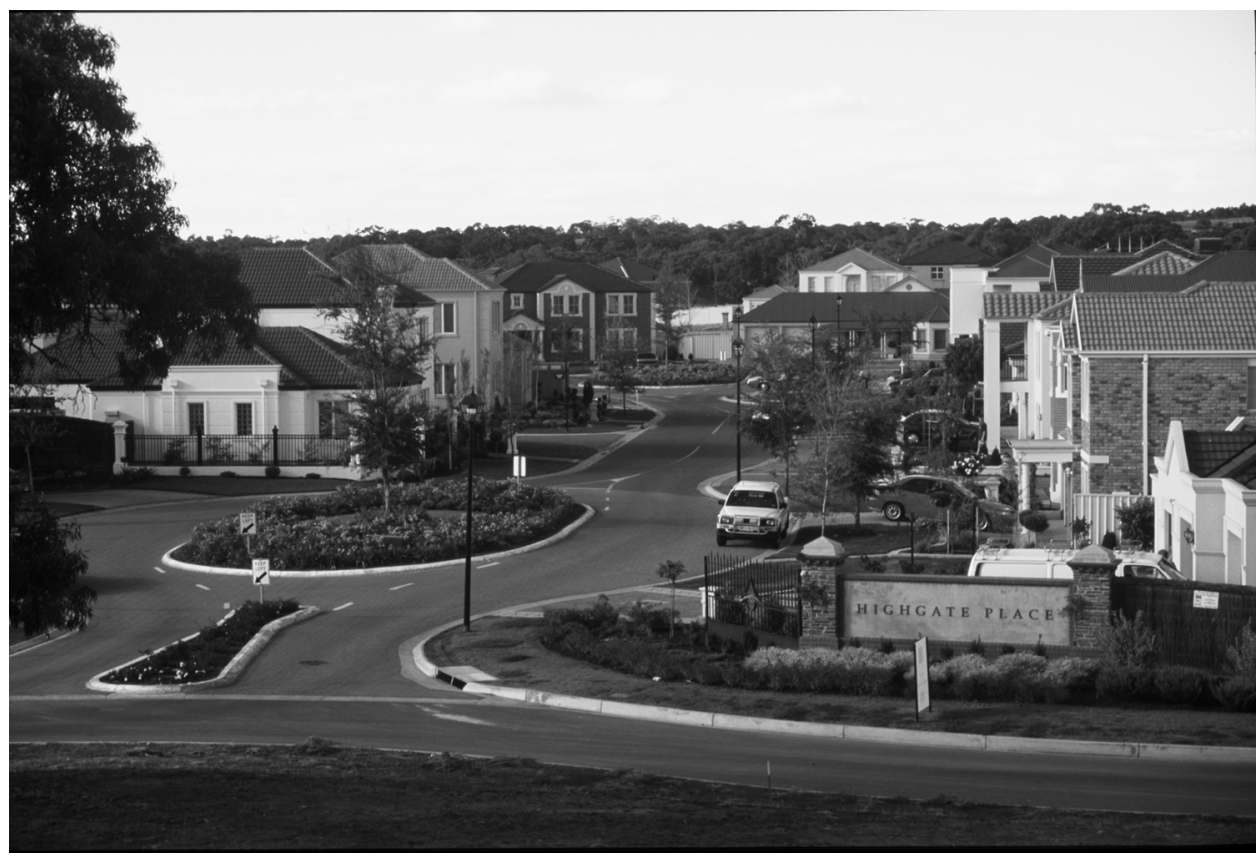

Figure 4. A typical Golden Grove Development streetscape taken in 2003, depicting the marketed and largely embraced identity of the area; one that upholds ideals of the 'good community'. Source: Image taken by the author.

between rationalized core Government objectives and marginalized ideology. The Dunstan Labor Government championed 'community planning' objectives, as borne out by the welfarist rationalities and techniques of government advocated by the SALC. The early social interventionist goals of the SALC were to 'prevent and/or correct anomalies of resource allocation and injustices in the distribution of goods and services' ${ }^{49}$ Consequently, the initial planning documents for the Golden Grove parcel of land reflected welfarist forms of planning; planning practices that were initiated by, funded by and implemented by the Government. With the defeat of the Labor Government in the late 1970s and the subsequent restructure of the Land Commission, the role for 'community planners' in Government development projects was marginalized. Although a welfarist mode of government in Australia did not last long, it did establish the framework for the future planning of the Golden Grove site. The return of a South Australian Labor Government under the leadership of John Bannon in late 1982 saw the re-instatement of a commitment to social planning practices - including the strengthening of social-economic relations - by the South Australian Government.

As this paper has demonstrated, the shifts from welfarism to neo-liberalism were not clear cut; however, they were significant and persistent. The deregulation of the SALC was evidence of the shift towards a neo-liberal mode of government. The changes to State Planning policies and procedures, specifically to facilitate development of the Golden Grove site, further evidenced this neo-liberal turn. In addition, the choice of a joint venture partnership 


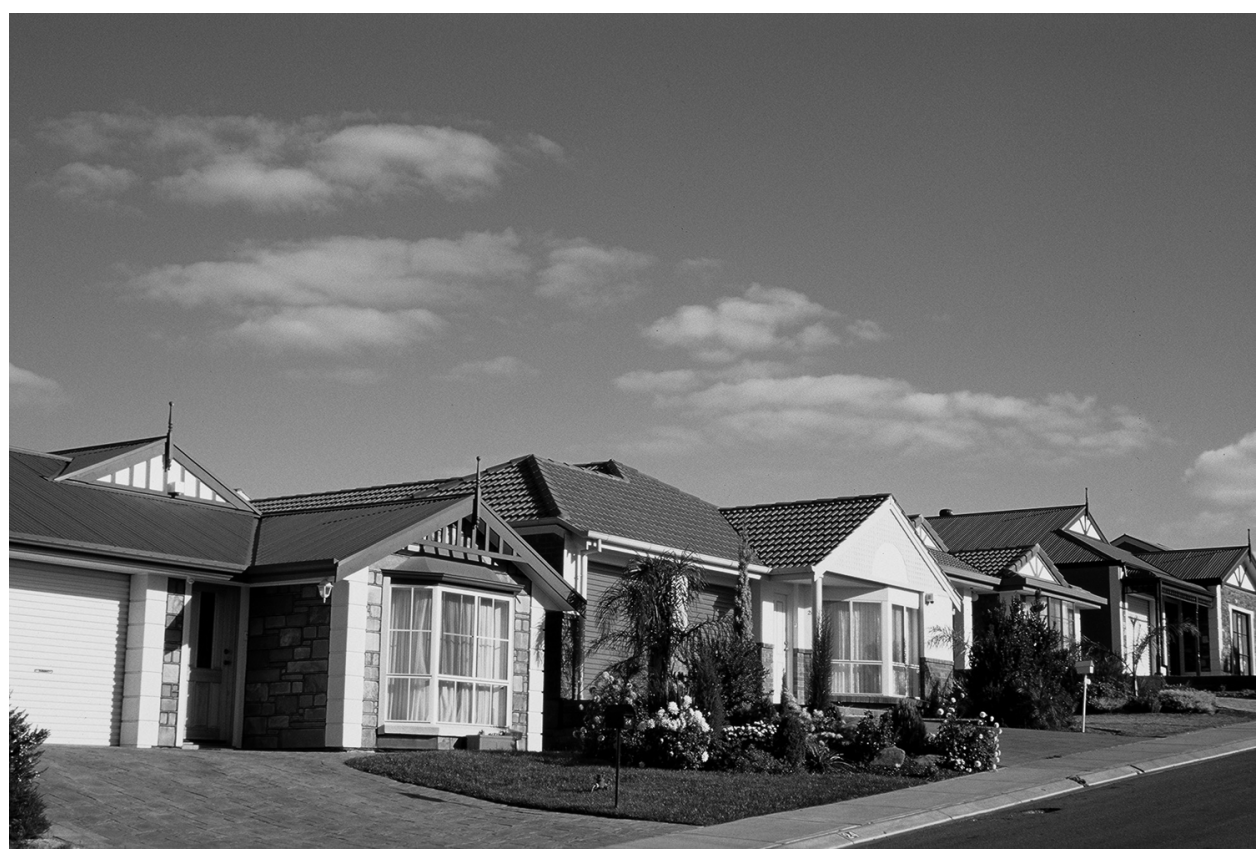

Figure 5. The Golden Grove Development 2003, a 'safe', 'pleasant' and 'risk minimized' landscape. Building type and tenure combined with subdivision pattern produced a mostly monotonous landscape; the very outcome that the early planning of the site was supposed to avoid. Source: Image taken by the author.

and in particular the management structure thereof, and the continued competitive quest for the development to be better than other suburban developments, are characteristic of neo-liberal modes of government. As noted by Gleeson and Low at the beginning of this paper, neoliberalism is characterized by deregulation (in this instance, of planning policies and procedures), privatization (the joint venture partnership) and competition (the commodifing of community). As already suggested, while the ratification of the indenture ensured neo-liberal techniques of government would predominate, the early welfarist rationalities begat the Paramount Objectives, which were to be the 'ten commandants' of the joint venture committee. The Paramount Objectives depicted particular ideals of the 'good community' and the joint venture committee upheld these objectives as a means to produce such ideals; ideals that were 'universal' and 'true'.

Ideals of community as produced by the discourses of the Golden Grove Development are not dissimilar to their historical forbears. They remain associated with aspirations to "the good life', a more caring and sharing world, a more connected and united world. Throughout the latter part of the twentieth century, 'fully planned communities' in Australia were (and still are) marketed as offering a new world of old-time values and the realization of particular concepts of 'the Australian Dream': home ownership in suburbia, a 'safe' and pleasant environment, a secure investment and ideals of community. An imagined gemeinschaft village 
life is still often portrayed as a popular contemporary image of 'community'. Such an image privileges face-to-face relationships and depicts small scale, place-based, self-contained and self-referential residential collectives. This ideal is not far from that espoused by Ebenezer Howard at the beginning of the twentieth century in his Sociable Cities/Garden City model. The values and the mechanisms of government intrinsic to the production of ideals of community, as produced by the discourses of the Golden Grove Development, differed from the historical 'village community' rhetoric. In this case, ideals of the 'good community' become marketable commodities associated with securing economic gains and, at the same time, minimizing the risks attached to deviance, resistance, difference and diversity.

The aim of this paper has been to reveal, and thereby contest, suburban planning techniques and practices, and in particular, those that established the Golden Grove Development as a 'fully planned community'. The story told has revealed how ideals of community were constituted in the late twentieth century; this telling opens up other possibilities to think about practices of suburban planning within South Australia, Australia and internationally.

\section{Acknowledgements}

This paper is drawn from my $\mathrm{PhD}$ thesis which was completed in 2005. In addition, I wish to acknowledge and thank the two anonymous referees for their insightful and supportive comments on an earlier draft of this paper and also the encouragement given by my fellow URP colleagues at Griffith University.

\section{Notes}

1. C. Bosman, 'The Making of Suburban Heritage: Building "Community", Cultural Significance and Planning Practices', in Past Matters: Heritage and Planning History - Case Studies From The Pacific Rim, ed. C. Miller and M. Roche (Newcastle: Cambridge Scholars, 2007), 81-103.

2. S. Hamnett and A. Hutchings, 'The Era of Strategic Planning', in With Conscious Purpose, ed. A. Hutchings (Adelaide: Planning Institute of Australia [S.A. Division], 2007), 117-31.

3. Golden Grove Community Planning Team, Golden Grove Community Plan (Adelaide, 1990).

4. For a detailed account of the Golden Grove Development, see C. Bosman, "Building "Community": Sites of Production, Planning Practices and Technologies of Suburban Government in the Making of the Golden Grove Development, 1984-2003' (PhD thesis, University of South Australia, Adelaide, 2005).

5. C. Bosman, 'Homes for Everyone', Journal of Australian Studies 80 (2004): 131-45.

6. See G. Wilson-Doenges, 'An Exploration of Sense of Community and Fear of Crime in Gated Communities', Environment and Behavior 32 (2000): 597-611; G.E. Frug, City Making: Building Communities without Building Walls (Princeton, NJ: Princeton University Press, 1999).

7. C. Bosman, 'Building Community Places - Machizukuri - Neo-Liberalism, Suburbanization and "Americanization", International Planning Studies 12 (2007): 1-17.

8. C. Bosman, 'A District Package: Constituting Community - Golden Grove 1984-2002', Journal of Australian Studies 76 (2003): 17-26.

9. Tract S.A., Comprehensive Development Plan: Modbury-Golden Grove (Adelaide: South Australian Land Commission, 1976); Golden Grove (Indenture Ratification) Act, 1984 (Adelaide: Golden Grove Community Planning Team, 1984).

10. P. McGuirk, 'Neoliberalist Planning? Re-Thinking and Recasting Sydney's Metropolitan Planning', Geographical Research 43 (2005): 59-70, 59-60.

11. N. Rose and P. Miller, 'Political Power Beyond the State: Problematics of Government', British Journal of Sociology 43 (1992): 173-205, 188.

12. M. Dean, Governmentality: Power and Rule in Modern Society (London: Sage, 1999), 153-4.

13. B. Gleeson and N. Low, Australian Urban Planning (St Leonards, NSW: Allen \& Unwin, 2000), 36. 
14. B. Gleeson and N. Low, 'Revaluing Planning: Rolling Back Neo-Liberalism in Australia', Progress in Planning 53 (2000): 83-164.

15. C. Forster and M. McCaskill, 'The Modern Period: Managing Metropolitan Adelaide', in With Conscious Purpose, ed. A. Hutchings (2007), 85-108, 85.

16. A. Hutchings, 'Consistent Vision: The Planning of Metropolitan Adelaide 1962-1992', in Spirited Cities: Urban Planning, Traffic and Environmental Management in the Nineties, ed. R. Freestone (Sydney: Federation Press, 1993), 190-208.

17. Gleeson and Low, 'Revaluing Planning', 95-6.

18. See E. Whitlam, 'The Political Powers and Policies Needed for Effective Planning', Architecture in Australia 60 (1971): 709-12.

19. S. Hamnett et al., 'South Australian Planning in the 1990's, Planning Education Foundation of South Australia' (working paper No. 6, 1997), 2.

20. Bosman, 'Building Community Places'.

21. Forster and McCaskill, 'The Modern Period', 105

22. Forster and McCaskill, 'The Modern Period', 99.

23. Forster and McCaskill, 'The Modern Period'.

24. Tract S.A., Modbury-Golden Grove Structure Plan: The Structure Plan (Adelaide: South Australian Land Commission, 1976), 8.

25. Tract S.A., Modbury-Golden Grove Structure Plan: The Future Strategies (Adelaide: South Australian Land Commission, 1976), 8.

26. L.G. Curtis and Associates, Brief for Marketing Strategies Report Modbury-Golden Grove (Adelaide: South Australian Land Commission, 1977).

27. Tract S.A., Comprehensive Development Plan, 8.

28. See C. Garnaut, Colonel Light Gardens: Model Garden Suburb (Darlinghurst, NSW: Crossing Press, 1999).

29. See M. Peel, Good Times, Hard Times (Victoria: Melbourne University Press, 1995).

30. See J. Wanna, 'Urban Planning under Social Democracy - The Case of Monarto, South Australia', Australia Quarterly 54 (1982): 260-70.

31. Tract S.A., Modbury-Golden Grove Structure Plan: The Future Strategies, 2.

32. A. Fogg, Process, Procedures and Plans (a monograph, Canberra: Australian Institute of Urban Studies no. 87, 1980), 259.

33. Official reports of the parliamentary debates (HANSARD), session of 1977-78 (South Australia, Government Printer, March 14, 1987), 2179-87, 2179.

34. B. Badcock, 'Land and Housing Provision', in The State As Developer: Public Enterprise in South Australia, ed. K. Sheridan (Adelaide: Royal Australian Institute of Public Administration, 1986), $166-86,176$.

35. Forster and McCaskill, 'The Modern Period'.

36. Forster and McCaskill, 'The Modern Period', 106.

37. Northage and Associates, Golden Grove: Development Initiatives. A Study of Objectives and Arrangements for the Golden Grove Development (Adelaide: Department of Environment and Planning, 1983), i.

38. B.L. Bentick, An Evaluation of the Relationship Between the South Australian Land Commission and the Private Sector (Queensland: UDIA [S.A. Division], 1977).

39. Tract S.A., Modbury-Golden Grove Structure Plan: The Structure Plan, 8.

40. See M. Lennon, 'The Revival of Metropolitan Planning', in The Australian Metropolis: A Planning History, ed. S. Hamnett and R. Freestone (St Leonards, NSW: Allen \& Unwin, 2000), 149-67.

41. Northage and Associates, Golden Grove: Development Initiatives, ii.

42. Personal communication, 2001.

43. Unpublished feasibility study review group report.

44. See B. Badcock, 'Land and Housing Provision'.

45. See 'Bannon's \$1300m Land Deal Queried', National Times, November 2-8, 1984, 22; 'Delfin Property Deal Rocks S.A. Land Trust', National Times, November 30-December 6, 1984, 47.

46. Personal communication; Also see J. Blaess, 'Golden Grove: An Opportunity for Urban Innovation' (Grad. Dip. Regional and Urban Planning thesis, School of Built Environment, South Australian Institute of Technology, 1985). 
47. Golden Grove (Indenture Ratification) Act, 1984, 5

48. Golden Grove (Indenture Ratification) Act, 1984.

49. Gleeson and Low, Revaluing Planning, 124.

\section{Notes on contributors}

Caryl is a lecturer in the Griffith School of Environment, Griffith University. She holds a PhD in urban planning, a Bachelor of Architecture and a National Diploma in Architecture. Caryl has worked in architectural practices in South Africa, London and Australia and taught in both architectural and planning degree programmes. Her research interests focus on past and present urban development theories, practices and processes, particularly in relation to ideals of community, sub/urban development and climate change. Current areas of research include placemaking, urban design and housing in tourist cities. 